\title{
DIÁLOGOS ENTRE DISCURSOS OFICIAIS E DOS PERIÓDICOS ACADÊMICO-CIENTÍFICOS: AS PRÁTICAS SOCIAIS DE ESCRITA, DE PRODUÇÃO E DE CIRCULAÇÃO DO CONHECIMENTO
}

\author{
DIALOGUES ESTABLISHED BETWEEN OFFICIAL DISCOURSE \\ AND ACADEMIC-SCIENTIFIC JOURNALS: SOCIAL PRACTICES OF \\ WRITING, PRODUCTION AND DISCLOSURE OF KNOWLEDGE
}

Ângela Francine Fuza'

\begin{abstract}
RESUMO: Periódicos científicos brasileiros das diferentes áreas do conhecimento Sociais, Linguística, Letras e Artes, exatas, Saúde, Engenharias e Humanas - foram analisados a fim de verificar os diálogos estabelecidos entre eles e documentos oficiais envolvidos na prática da produçăo científica no país. 0 estudo caracteriza-se como qualitativo-interpretativo, com procedimentos investigativos de base documental, segundo os princípios teóricos dos Letramentos Acadêmicos. Os levantamentos dos dados de cada periódico resumiram-se em histórico, comissăo editorial, apoios e indexadores e foram colocados em diálogo com as características dos discursos oficiais. Os resultados evidenciam que os periódicos analisados dialogam e respondem aos discursos oficiais e das agências de pesquisa em proporçóes variadas, sendo bastante evidente a resposta das revistas aos discursos das agências de fomento à pesquisa e de regulamentaçâo de atividades científicas, em funçăo de seu caráter deliberativo e delimitado. O fato de haver esse diálogo evidencia as relaçóes de poder existentes nas práticas sociais de escrita, de produçâo e de circulaçăo do conhecimento, indicando que a utilizaçâo da linguagem envolve diferentes instâncias e se dá realmente em um elo discursivo contínuo.
\end{abstract}

PALAVRAS-CHAVE: diálogo; discurso oficial; periódicos acadêmico-científicos.

ABSTRACT: Brazilian scientific journals of different fields of study, such as Social Studies, Linguistics, Languages, Literature and Arts, Exact Sciences, Engineering and Humanities, have been analyzed with a view to assessing the dialogues established among those fields of study and the official documents involved in scientific production of Brazil. This is a qualitative-interpretative study carried out by means of documentbased investigative procedures, following the theoretical principles advocated by Academic Literacy studies. The data collected from each journal can be summarized as follows: history, editorial committee, support and indexes, and a dialogue between such data as well as the characteristics of official discourse was established. Results evince that the journals analyzed herein establish a dialogue and respond to official

Doutora em Linguística Aplicada (Unicamp), professora da Universidade Federal do Tocantins. Este texto é baseado na tese de Doutorado da autora (FUZA, 2015), que foi desenvolvida com apoio financeiro do CNPq. E-mail: angelafuza@uft.edu.br. 
discourse as well as to research agencies in different proportions. The response of journals towards research agencies and scientific activity regulation discourse is quite evident due to being of deliberative and outlined nature. This dialogue evinces the relationships of power established within social practices of writing, production and disclosure of knowledge, thus suggesting that language use involves different spheres, thereby taking place in a continuous discursive connection.

KEYWORDS: dialogue; official discourse; academic-scientific journals.

\section{CONSIDERAÇÕES INICIAIS}

Amaldiçoado pelos deuses, Sísifo foi condenado a carregar uma grande pedra até o topo de uma montanha, para deixá-la rolar ladeira abaixo e em seguida recomeçar tudo outra vez. A lenda de Sisifo é uma metáfora apropriada para a história da ciência moderna no Brasil, onde os sucessos têm sido poucos e efêmeros, mas a persistência e o entusiasmo nunca faltaram (SCHWARTZMAN, 2001, p. 12).

Este texto dialoga com outros tantos estudos que o antecedem a respeito dos periódicos científicos2 (KRONICK, 1976; MEADOWS, 1974[1999]; BARATA, 2010; STUMPF, 1996; FREITAS, 2005; HAYASHIDA, 2012) e representa mais um elo de uma cadeia dialógica que propóe a continuidade da reflexăo a respeito da temática, a fim de discutir o papel dos periódicos, em relaçăo aos discursos oficiais, a partir do olhar, suscitado por discussóes sobre o letramento acadêmico, feitas por estudiosos dos Novos Estudos do Letramento (STREET, 1984; CURRY; LILLIS, 2014, entre outros).

A lenda de Sísifo abre esta seçâo, uma vez que é considerada uma metáfora apropriada para a história da ciência moderna no Brasil. Conforme carta divulgada pelo Fórum de Editores da Fiocruz (2015), que questiona os movimentos em curso para a internacionalizaçấo dos periódicos brasileiros, vive-se no Brasil um crescimento da produçáo científica com o aumento do número de artigos publicados em periódicos nacionais e internacionais. Apesar do crescimento de 145\%, entre 2002 e 2012, nas publicaçōes, o desempenho do país no âmbito global ainda é limitado, uma vez que năo cresce o número de artigos de pesquisadores brasileiros com colaboradores internacionais.

Este texto, qualitativo-interpretativo, com procedimentos investigativos de base documental, objetiva verificar alguns diálogos estabelecidos entre os discursos dos periódicos científicos selecionados de diferentes áreas do conhecimento e os discursos dos documentos oficiais envolvidos na prática da produçăo científica no país: Constituiçāo Federal do Brasil (CF, BRASIL, 1988); Lei de Diretrizes e Bases da Educaçâo Nacional (LDB, BRASIL, 1996); Plano Nacional da Educaçâo (PNE, BRASIL, 2014-2024), os discursos postulados pelas Agências de Fomento dos Estados, pela Coordenaçăo de Aperfeiçoamento de Pessoal de Nível Superior (Capes) e pelo Conselho Nacional de Desenvolvimento Científico e Tecnológico (CNPq), relacionando dados coletados da revista no que se refere à sua história, comissăo, indexadores, dentre outros fatores. O estudo de tais relaçôes de diálogo, de respostas das revistas aos documentos oficiais

Neste texto, empregam-se os termos: periódico e revista, como sinônimos, apesar de alguns estudiosos os diferenciarem em certas situaçôes (STUMPF, 1996). 
e às práticas de escrita é uma forma de se verificar como os discursos ecoam ao serem concretizados, instituindo-se dentro das comunidades acadêmicas.

Ao pensar no universo da produçăo e da circulaçăo da ciência no Brasil, verifica-se que ele é constituído de diferentes discursos, como o dos documentos oficiais e dos periódicos científicos (FUZA, 2016). Entender a posiçăo do periódico dentro desse contexto de produçăo é uma forma de focalizar os aspectos sócio-históricos de constituiçâo desse suporte e dos artigos que o constitui, possibilitando entender a produçâo da escrita científica como inter-relacionada a outros fatores sociais.

Segundo Pasquotte-Vieira (2014), é preciso, entâo, compreender, a escrita acadêmico-científica em meio a um processo que integra o papel do sujeito discursivo, os espaços de discussăo, de negociaçăo, as normas de produçăo, dentre outros fatores, segundo as "relaçóes de poder existentes no processo de interlocuçâo [que envolve a escrita acadêmica]" (PASQUOTTE-VIEIRA, 2014, p. 71-72). Os diálogos estabelecidos entre os periódicos e os discursos permitem compreender os letramentos acadêmicos presentes no contexto universitário nâo apenas em seu âmbito, mas envolto por questôes, como as políticas científicas e as propostas dos discursos oficiais.

Existem, portanto, relaçôes envolvendo todo o processo de produçăo e de circulaçăo dos conhecimentos. Há, inicialmente, o discurso oficial postulando normas e posturas de escrita e de pesquisa. Em diálogo, há os periódicos que buscam atender às necessidades impostas, ao mesmo tempo em que abordam temáticas e problemáticas envoltas em sua comunidade acadêmica. Há, ainda, o sujeito pesquisador que analisa, produz e procura a publicaçáo e a circulaçáo do seu saber dentro da comunidade, fato que o constitui como indivíduo inserido dentro de sua esfera comunicativa. Todos esses diálogos instaurados representam modos culturais de utilizaçâo da linguagem. Dessa forma, justifica-se a necessidade de compreensăo dos diálogos entre os discursos oficiais e os discursos dos periódicos que constituem um dos elos constituintes do processo de escrita acadêmico-científica.

Este texto, vinculado ao grupo de pesquisa: “Escrita: ensino, práticas, representaçôes e concepçōes" (Unicamp/CNPq) e ao projeto de pesquisa: "Práticas de letramento acadêmico-científicas: a constituiçăo dos discursos escritos" (UFT), discorre brevemente, em primeiro lugar, a respeito dos periódicos científicos e as teorias do Letramento Acadêmico; na sequência, trata da caracterizaçăo da pesquisa e, por fim, apresenta a análise dos dados observados.

\section{PERÍODICOS CIENTÍFICOS: DIÁLOGOS COM OS PRINCÍPIOS DO LETRAMENTO ACADÊMICO}

Schwartzman (2001, p. 13) retrata a formaçâo das comunidades científicas no Brasil, reafirmando que a ciência se refere a uma comunidade de indivíduos "que empregam com entusiasmo o melhor da sua inteligência e criatividade. Os resultados desse trabalho - artigos, dados científicos, aplicaçōes tecnológicas - năo passam da ponta de um iceberg que náo se pode sustentar sem sua base oculta: os indivíduos que os produzem". Essas colocaçóes já apontam para o sentido de que a produçáo escrita da ciência, representada, aqui, pelo periódico e pelo artigo científico, dá-se por meio de diversos fatores, especialmente pelos indivíduos que produzem e constituem suas 
comunidades científicas. De acordo com Hayashida (2012), há muitos estudos sobre periódicos científicos no Brasil e a grande maioria é da área da Ciência da Informaçấo, apesar de constar também em áreas como História, Psicologia, Letras e Linguística.

Ainda que seja uma obra de 1974, o livro "Communication in Science", com traduçăo em 1999, "A comunicaçăo científica", de Meadows, continua a ser indispensável quando se aborda a questăo da comunicaçăo científica que, segundo o autor, situa-se no próprio coraçáo da ciência e que a comunicaçấo é tăo importante quanto à própria pesquisa, pois enquanto ela nâo for analisada e aceita pelos membros da comunidade é como se nâo existisse. Crespo e Caragnato (2004) compartilham da mesma opiniăo de Meadows, no sentido de que concebem a comunicaçâo científica como sendo indispensável à atividade científica, haja vista que permite somar os esforços individuais dos membros dessa comunidade.

Para Oliveira (2006, p. 19), a comunicaçâo científica "proporciona a cooperaçăo e integraçăo entre os pesquisadores, contribui para o reconhecimento das descobertas, confirma competências e estabelece credibilidade e aceitaçấo do pesquisador na comunidade científica". A comunicaçăo entre os cientistas e o seu público sempre existiu e pode ser realizada formal ou informalmente na sociedade. Para Meadows (1999), a comunicaçáo informal estaria relacionada às comunicaçôes em congressos e conferências, discursos, conversas etc. A comunicaçăo formal tem uma existência mais duradoura e está concentrada na literatura: livros, periódicos, relatórios etc. No âmbito deste trabalho, trata-se da comunicaçăo científica formal: o periódico científico, porque se configura como um dos principais veículos da comunicaçăo científica e tem, sobretudo, três funçōes distintas:

1. ser arquivo da ciência, pois registram de forma permanente as descobertas e avanços científicos; 2 . ser veículos de divulgaçăo e comunicaçăo do saber, uma vez que é através deles que o conhecimento fica disponível à comunidade; 3. ser meios de conferir prestígio e reconhecimento aos autores, pois os artigos săo avaliados pelos pares antes de serem publicados (COSTA, 2008, p. 17).

Conforme Stumpf (1996), as revistas científicas, desde que começaram a ser publicadas no século XVII, passaram a exercer importante papel no processo de comunicaçăo da ciência. Surgiram como uma evoluçăo do sistema particular e privado de comunicaçấo, que era feito por meio de cartas entre os investigadores e das atas ou memórias das reunióes científicas. Havia o uso de cartas entre os cientistas como forma de transmissáo das ideias, eles trocavam correspondências com conhecidos que nâo refutariam as suas ideias. Por serem muito pessoais, lentas para a divulgaçăo de novas ideias e limitadas a um pequeno círculo de pessoas, elas náo se constituíram no método ideal para a comunicaçăo dos dados científicos e das teorias. Aqueles que utilizavam as cartas e as atas para divulgaçăo pertenciam aos "colégios invisíveis" (invisible college). Estes grupos recebiam tal denominaçăo para se diferenciarem dos colégios universitários oficiais (oficial university college) que serviram de base para a criaçâo das sociedades e academias científicas. Aconteciam encontros entre seus membros, muitos deles secretos, nos quais realizavam experimentos de pesquisa, avaliavam os resultados e discutiam sobre temas filosóficos e científicos. Os relatos e as conclusôes desses encontros eram, muitas vezes, registrados e as cópias, distribuídas como cartas ou atas a amigos que estavam desenvolvendo pesquisas análogas. Quando o número de participantes dos colégios se tornava muito grande, os membros se dispersavam ou se 
transformavam em organizaçóes mais estruturadas e visíveis, como as academias e as sociedades científicas.

As formas de divulgaçăo mencionadas - cartas e atas - apenas influenciaram o surgimento das revistas que, com o tempo, assumiram o papel de principais divulgadores das investigaçôes (STUMPF, 1996). As revistas năo aboliram a existências desses dois veículos, mas sim possibilitaram uma definiçấo de papel entre os canais de divulgaçăo: a correspondência tomou apenas um caráter de comunicaçăo pessoal entre os cientistas, e as atas, também conhecidas como memórias ou anais, passaram a se constituir em um documento de registro dos trabalhos apresentados em reuniōes científicas e profissionais.

Após se constituírem, as revistas passaram a fazer parte das comunidades acadêmicas como forma de representá-la, expondo as ideias, as crenças e as informaçóes estudadas dentro de cada área do conhecimento. Para Freitas (2005, p. 54), “além de fonte privilegiada da história da ciência, o periódico científico pode ser considerado um espaço institucional da ciência, pois se insere dentro do universo das realizaçôes e comunicaçăo das atividades científicas". Nele săo divulgados resultados das pesquisas sobre determinados assuntos, tornando-o meio ágil de atualizaçâo das informaçóes na academia e nas áreas do conhecimento. Rodrigues e Marinho (2009) complementam que a relevância da publicaçăo no periódico para o cientista está na divulgaçăo do "conhecimento originado de suas atividades de pesquisas, assim como, aliás, para o historiador, que nelas tem documentos valiosos, reveladores de preocupaçóes, pensamentos e opinióes de determinadas épocas a respeito de acontecimentos e personagens" (RODRIGUES; MARINHO, 2009, p. 10).

Neste texto, consideram-se os periódicos como documentos com discursos próprios que se efetivam no diálogo com outros discursos que se interdependem, no âmbito das comunidades acadêmicas/científicas. De acordo com os estudos de Jacobina (1999), pautando-se em Kuhn (1990), define-se comunidade científica/acadêmica por meio de um truísmo:

- a estrutura comunitária da ciência é "aquela formada pelos praticantes de uma especialidade científica", pois, ao longo dos anos, a comunidade científica desenvolveu seus próprios mecanismos de defesa contra o insumo de informaçóes em excesso, privilegiando a especializaçăo dos pesquisadores dentro de suas áreas de interesse. Este fato é evidente também em títulos de periódicos que se apresentam concisos e objetivos, destinando-se às suas áreas de interesse (MEADOWS, 1999);

- unidade produtora e legitimadora do conhecimento científico, haja vista a especialidade dos pesquisadores que constituem a comunidade científica, considerada local de produçấo e de legitimaçăo do conhecimento, já que é responsável por julgar se uma contribuiçăo é importante (MEADOWS, 1999, p. 82);

- quanto aos seus integrantes, estâo submetidos à educaçăo e à iniciaçâo profissional similares; absorvem praticamente a mesma literatura técnica;

- a comunicaçăo entre os membros de uma comunidade científica é ampla e os julgamentos profissionais, relativamente unânimes, uma vez que constituem a única audiência e os únicos juízes do trabalho dessa comunidade;

- a comunicaçâo entre diferentes comunidades é árdua, quando nâo impossível, devido às particularidades de cada área. 
Entender como se define essa comunidade acadêmica é fundamental para tratar da escrita em periódicos de diferentes áreas de conhecimento, pois eles săo locais de normas, há uma obrigatoriedade na academia em produzir; assim, dentro de todo o contexto acadêmico, com todas as suas especificidades, as revistas sistematizam e padronizam o que se tem no contexto. Dessa forma, manifesta-se, de um lado, a sistematizaçáo e normatizaçăo da escrita nos periódicos e, de outro, o movimento que as áreas de estudo realizam na produçâo de conhecimento, pois "a linguagem funciona diferentemente para diferentes grupos, na medida em que diferentes materiais ideológicos, configurados discursivamente, participam do julgamento de uma dada situaçăo" (BRAIT, 2001, p. 80).

Para Oliveira (2006, p. 37), o letramento faz que as práticas tenham um âmbito social, em virtude de fatores e de convençôes sociais que estabelecem "o uso da escrita em determinada comunidade, ou dada esfera da atividade humana - e uma dimensâo individual, por conta da história e das experiências de vida de cada indivíduo que pertence à comunidade". Ou seja, a orientaçăo do discurso năo se dá em virtude dos aspectos homogeneizadores da escrita, mas também em funçăo dos elementos que sâo heterogêneos e que o regulam: "a escrita acadêmica, segundo essa concepçăo, caracteriza-se por movimentos em concorrência, pela pluralidade de vozes e subjetividades" (WILSON, 2009, p. 100 apud OLIVEIRA, 2010, p. 100).

Conforme já exposto, Pasquotte-Vieira (2014, p. 71-72) afirma ser importante "a compreensăo da escrita acadêmico-científica segundo as 'relaçóes de poder existentes no processo de interlocuçấo'". Neste artigo, ao evidenciar os diálogos estabelecidos entre os periódicos e os discursos oficiais, concebendo-se a escrita como prática social (STREET, 1984), permite-se, de certa forma, compreender o letramento presente no contexto acadêmico nâo apenas em seu âmbito, mas envolto por questôes, como as políticas científicas, as propostas dos discursos oficiais. Sendo assim, a perspectiva do Letramento Acadêmico possibilita tratar da inserçăo do periódico nas práticas letradas acadêmicas constituídas, por um lado, por suas escolhas como área de conhecimento, e, por outro, pelas relaçôes com interlocutores, "aqueles que, na hierarquia das relaçôes acadêmico-institucionais, estabelecem a regra do jogo, sejam eles [...] avaliadores de projetos [...], os pareceristas e editores de publicaçôes [...]" (PASQUOTTE-VIEIRA, 2014, p. 71-72), acrescentando-se, aqui, os documentos oficiais, aparatos institucionais e governamentais que regulamentam a produçâo do conhecimento (CURRY; LILLIS, 2014).

\section{CARACTERIZAÇÃO DA PESQUISA E SELEÇÃO DOS PERIÓDICOS}

Este estudo caracteriza-se como qualitativo-interpretativo, com procedimentos investigativos de base documental. Ante a análise de materiais documentais, como documentos oficiais e periódicos, optou-se por denominar os processos que envolveram a coleta desses materiais e o levantamento de características como sendo documental.

Conforme Lüdke e André (1986), deve-se apreciar e valorizar o uso de documentos em pesquisas, haja vista que possibilitam ampliar o entendimento dos objetos cuja compreensẫo necessita de contextualizaçấo. Além de permitirem acrescentar a dimensâo do tempo à compreensâo do social (CELLARD, 2008). De acordo com Cellard (2008), os documentos sâo divididos em dois grupos: os públicos e os privados. Os primeiros săo 
subdivididos em arquivos públicos - compreendendo os arquivos governamentais, os arquivos do estado civil, que nem sempre săo acessíveis - e documentos públicos náo arquivados - incluindo revistas, periódicos, anúncios, documentos em geral etc. Os materiais analisados, neste estudo, como os periódicos, em diálogo com documentos oficiais, podem ser considerados como públicos năo arquivados, já que estăo passíveis de estudo e de análise.

Conforme Silva, Almeida e Guindani (2009), no estudo documental, a análise de conteúdo é uma das formas de interpretá-lo. De acordo com Lüdke e André (1986), o processo de análise de conteúdo dos documentos é iniciado com a decisâo sobre a "Unidade de Análise" que se apresenta de duas formas: unidade de registro e unidade de contexto. Este texto se alinha à unidade de registro, pois foram selecionados segmentos específicos do conteúdo para fazer a análise, como, por exemplo, a frequência com que apareceu no texto uma expressăo, um tema ou um determinado item, o que pode caracterizar este estudo como de cunho documental, embora náo faça uso das técnicas específicas dessa metodologia de estudo. Cellard (2008) afirma que, para um trabalho de conteúdo relevante, é preciso a leitura compreensiva do material e sua descriçăo, sendo que, na abordagem qualitativa, além desses fatores, faz-se fundamental a inferência e as interpretaçōes sobre o que se descreve.

A fim de verificar como se dăo os diálogos entre as revistas e os discursos oficiais, foram selecionados os periódicos de acordo com alguns critérios: nota no Qualis A1; áreas do conhecimento; modalidade da contribuiçăo; tempo de existência da revista e ano da coleta dos dados.

Optou-se pelos periódicos A1, pois refletem, de certa forma, aquilo que é esperado pelo universo acadêmico, em termos de excelência, haja vista os critérios estabelecidos pelo Qualis, como publicaçăo reconhecida na área, condizente com as normas da ABNT, apresentando conselho editorial com membro do país e do exterior etc. ${ }^{3}$ Em relaçâo ao número de periódicos do estrato A1, destaca-se o Quadro 1:

Quadro 1: Levantamento dos periódicos do estrato A1 segundo WEBQUALIS (2012)

\begin{tabular}{c|c|c}
\hline ÁREA & $\begin{array}{c}\text { TOTAL DE REVISTAS } \\
\text { BRASILEIRAS A1 }\end{array}$ & $\begin{array}{c}\text { TOTAL DE REVISTAS } \\
\text { ESTRANGEIRAS A1 }\end{array}$ \\
\hline CIÊNCIAS AGRÁRIAS & 00 & 449 \\
\hline CIÊNCIAS BIOLÓGICAS & 00 & 753 \\
\hline CIÊNCIAS DA SAÚDE & 2 & 642 \\
\hline CIÊNCIAS EXATAS E DA TERRA & 5 & 307 \\
\hline CIÊNCIAS HUMANAS & 72 & 178 \\
\hline CIÊNCIAS SOCIAIS APLICADAS & 26 & 899 \\
\hline ENGENHARIAS & 1 & 78 \\
\hline LINGUÍSTICA, LETRAS E ARTES & 55 &
\end{tabular}

Fonte: baseado em Fuza (2015, p. 118).

3 Disponível em: <https://www.capes.gov.br/images/stories/download/avaliacaotrienal/Docs_de_area/ qualis/educacao.pdf> Acesso em: 10 jun. 2016. 
Diante do levantamento realizado, em todas as áreas de conhecimento investigadas, o número de revistas estrangeiras Al é superior ao número de periódicos brasileiros. Em uma escala crescente de número de revistas brasileiras A1, observa-se que as Ciências Agrárias e Biológicas năo possuem revista A1; as Engenharias têm uma; as Ciências da Saúde, duas; as Ciências Exatas e da Terra, cinco; as Ciências Sociais Aplicadas, vinte e seis; a área de Linguística, Letras e Artes, cinquenta e cinco; e, por fim, as Ciências Humanas possuem setenta e duas revistas.

Em funçăo da crença de que há múltiplas práticas envolvidas na produçâo da escrita, havendo variaçấo na produçâo dos discursos de uma área para outra, optou-se por selecionar periódicos de diferentes áreas do conhecimento. Os sites de todas as revistas brasileiras A1 foram visitados. Isso possibilitou a escolha de um periódico representativo de cada área em funçáo do tempo de existência da revista, consagrado em seu campo acadêmico, fundadas, respectivamente, em 1929 (Área: Multidisciplinar; subárea: Engenharias), 1950 (Ciências Humanas; subárea: História), 1979 (Ciências Sociais Aplicadas; subárea: Serviço Social), 1983 (Linguística, Letras e Artes; subárea: Letras/Linguística), 1985 (Ciências Exatas; subárea: Ensino), 1993(Ciências da Saúde; subárea: Enfermagem). Os periódicos năo săo identificados pelos nomes, mas sim por suas áreas de conhecimento, já que tal dado náo se faz relevante para o estudo.

Foi realizado, entăo, o levantamento dos dados de cada periódico que, de certa forma, resumiram-se em: histórico, comissăo editorial, apoios e indexadores, havendo algumas variaçôes que serâo evidenciadas. Na análise, os dados dos periódicos sâo colocados em diálogo com os dados sobre os discursos oficiais, elencados por Fuza (2015; 2016) e explicitados na seçấo seguinte.

\section{PERIÓDICOS SELECIONADOS: DIÁLOGOS COM OS DISCURSOS OFICIAIS}

Para a realizaçấo desta análise, entăo, retomam-se os estudos de Fuza (2015; 2016) que analisou, em momento específico de sua tese, os documentos oficiais que regem o Ensino Superior Brasileiro, assim como o desenvolvimento da pesquisa científica no país: a CF, a LDB, o PNE e os discursos das agências de fomento. Assim como a autora, busca-se demarcar, por meio da explicitaçăo desses diálogos, que os usos da escrita acadêmica năo podem ser tratados como neutros, universais, pois sâo socialmente determinados, sofrem influência do meio, no caso dos documentos de órgâos oficiais.

No âmbito dos discursos oficiais, a leitura e a análise possibilitaram perceber discursos com uma tendência àquilo que é democrático e àquilo que é deliberativo (FUZA, 2015), constituindo-se duas categorias de análise sobre os documentos oficiais: (1) discurso democrático no trato da ciência e (2) discurso deliberativo no trato da ciência:

Há aqueles [discursos oficiais] com foco mais democrático no trato da ciência, como ocorre na CF, na LDB, no PNE, os quais apresentam discursos perpassados pela noçăo da liberdade de estudar, de pesquisar e de divulgar, pensando-se no âmbito social da produçăo científica, sem que sejam mencionados aspectos normativos para que essa liberdade seja concretizada. Já os discursos das agências, do CNPq e da Capes [...] evidenciam um caráter normativo para a produçáo da ciência, tendo em vista que estabelecem normas diante da liberdade de publicar e de divulgar (FUZA, 2015, p. 101). 
Existem, portanto, diretrizes que conduzem a produçăo da ciência, a fim de que haja a divulgaçăo científica da pesquisa. Os discursos democrático e deliberativo náo săo excludentes, ao contrário, dialogam em busca da efetivaçăo da pesquisa e de sua publicaçăo, buscando-se a circulaçăo da ciência dentro das comunidades científicas.

A descriçâo e a análise dos discursos oficiais caracterizam de que forma essa voz oficial influencia na produçâo da ciência no país, haja vista que se instaura um diálogo entre o texto a ser produzido e seus interlocutores. Bakhtin/Volochinov (1992[1929]) e Bakhtin (2003[1979]) apontam tipos de interlocutores, sendo que os discursos oficiais podem ser entendidos como o "interlocutor terceiro" que representa um horizonte social definido e que estabelece determinada criaçăo ideológica do grupo social. Logo, além dos interlocutores reais que o produtor do enunciado encontra no momento da produçấo, há a voz de um terceiro no diálogo, caracterizada pela comunidade da qual faz parte, assim como pelos textos oficiais que circundam as práticas de produçáo científica. Por meio da descriçăo e da análise dos discursos, verifica-se o papel exercido pela voz oficial no trato da ciência.

Para analisar de que modo os discursos oficiais dialogam com os discursos dos periódicos selecionados para a análise, retoma-se o levantamento de características básicas voltadas à produçâo acadêmica da ciência, por meio do Quadro 2, proposto por Fuza (2015, p. 100):

\section{Quadro 2: Produção acadêmica da ciência nos discursos oficiais}

\begin{tabular}{|c|c|c|}
\hline \multirow{3}{*}{$\begin{array}{c}\text { DISCURSO } \\
\text { DEMOCRÁTICO }\end{array}$} & $\begin{array}{c}\text { CF } \\
\text { (BRASIL, } \\
\text { 1988) }\end{array}$ & $\begin{array}{c}\text { CF é o primeiro documento a tratar do direito à educação e, consequentemente, a } \\
\text { dar base para discussões envolvendo a produção científica; } \\
\text { o nível obrigatório e gratuito de ensino é somente o ensino fundamental, sendo que } \\
\text { o ensino superior não recebe atenção nesse sentido; } \\
\text { universidades: verdadeiras entidades produtoras de conhecimento, voltadas ao } \\
\text { ensino, à pesquisa e à extensão; } \\
\text { "liberdade de aprender, ensinar, pesquisar e divulgar o pensamento, a arte e o } \\
\text { saber" (CF, art. 206). }\end{array}$ \\
\hline & $\begin{array}{c}\text { LDB } \\
\text { (BRASIL, } \\
\text { 1996) }\end{array}$ & $\begin{array}{l}\text { busca-se a educação e a pesquisa no ensino superior, pensando justamente no } \\
\text { aspecto social do trabalho e do uso social que o indivíduo faz dos conhecimentos } \\
\text { (socialização acadêmica); } \\
\text { a universidade deve estimular a criação cultural, desenvolvendo nos sujeitos o } \\
\text { espírito científico e, consequentemente, o pensamento reflexivo; } \\
\text { possibilitar o desenvolvimento de sujeitos aptos a serem inseridos nos mais } \\
\text { diversos setores profissionais, levando ao desenvolvimento da sociedade brasileira; } \\
\text { incentivar, conforme o Inciso III, "o trabalho de pesquisa e investigação científica”; } \\
\text { comunicar os saberes por meio do ensino e de publicações; } \\
\text { busca pela volta dos conhecimentos para a realidade da qual o sujeito faz parte } \\
\text { (insider); } \\
\text { o atual papel assumido pela universidade, seja ela pública ou privada, é o de } \\
\text { relacionar a formação intelectual dos alunos e o mundo do trabalho. }\end{array}$ \\
\hline & $\begin{array}{c}\text { PNE } \\
\text { (BRASIL, } \\
\text { 2014) }\end{array}$ & $\begin{array}{c}\text { a universidade deve reunir a formação intelectual, o currículo e o mundo do } \\
\text { trabalho; } \\
\text { necessidade de elevar a qualidade da educação superior e ampliar a proporção de } \\
\text { mestres e de doutores do corpo docente em efetivo exercício no ensino superior; } \\
\text { busca da institucionalização da pesquisa, a fim de que haja a elevação do padrão } \\
\text { de qualidade; } \\
\text { consórcios entre instituições públicas de ensino superior, assegurando maior } \\
\text { visibilidade nacional e internacional às atividades de ensino, pesquisa e extensão; } \\
\text { intercâmbio científico e tecnológico, nacional e internacional, entre as instituições de } \\
\text { ensino, pesquisa e extensão. }\end{array}$ \\
\hline
\end{tabular}




\begin{tabular}{|c|c|c|}
\hline & FAP & $\begin{array}{c}\text { auxílio mediante aprovação de projeto de pesquisa; } \\
\text { projeto com configuração bastante padrão, independentemente da área de } \\
\text { estudo na qual o sujeito esteja inserido; } \\
\text { foco na avaliação dos projetos de pesquisa e não em artigos; } \\
\text { a Fapesp busca tratar do aspecto ético da pesquisa, indo além das } \\
\text { padronizações, postulando a necessidade de o trabalho estar em consonância } \\
\text { com os pressupostos estabelecidos pela comunidade acadêmica para as } \\
\text { pesquisas que envolvem seres humanos. }\end{array}$ \\
\hline $\begin{array}{c}\text { DISCURSO } \\
\text { DELIBERATIVO }\end{array}$ & $\begin{array}{l}\text { CNPq } \\
\text { Capes }\end{array}$ & 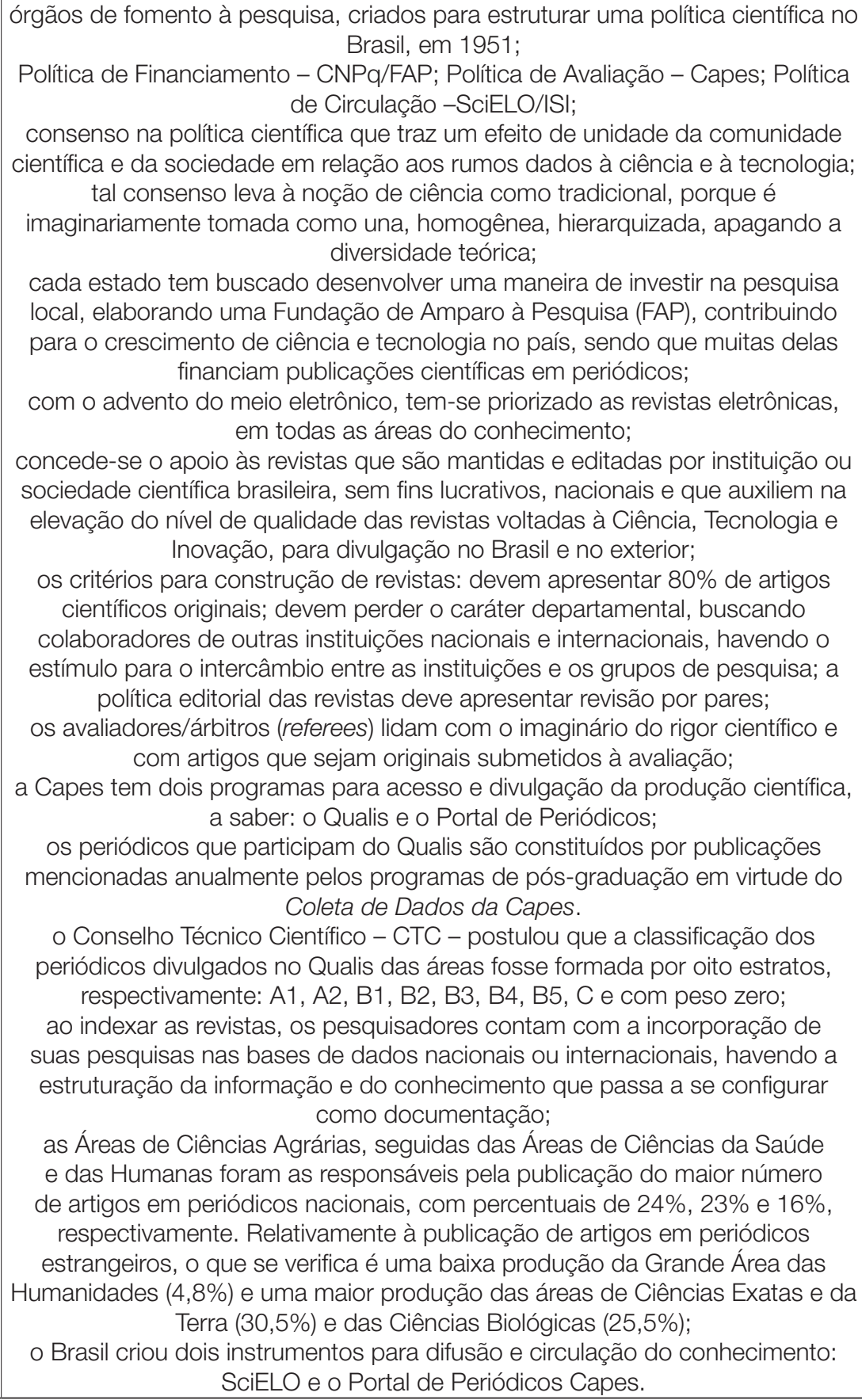 \\
\hline
\end{tabular}

Fonte: FUZA (2015, p. 100). 
Em relaçăo à CF, os periódicos buscam estabelecer um diálogo entre alguns discursos demarcados pelo documento. Isso náo ocorre em forma de citaçăo direta ou mençáo à $C F$, mas está subentendido quando se observam os dados da revista. Sendo assim, dois aspectos verificados na CF (BRASIL, 1988) săo apresentados nos periódicos, a saber: (1) "universidades: verdadeiras entidades produtoras de conhecimento, voltadas ao ensino, à pesquisa e à extensăo"; (2) "liberdade de aprender, ensinar, pesquisar e divulgar o pensamento, a arte e o saber" (CF, art. 206).

Apenas em duas revistas é possível verificar ambos os discursos em seus textos: Ciências Sociais Aplicadas e Linguística, Letras e Artes. Destacam-se, a seguir, os excertos que fazem, de certa forma, referência ao discurso que concebe a universidade como unidade de produçấo do conhecimento, voltada ao ensino, à pesquisa e à extensâo:

O periódico teve início em 1983, como uma iniciativa do Departamento de Linguística Aplicada para divulgaçáo das pesquisas de seus docentes e de outros que estivessem atuando na área (Linguística, Letras e Artes, grifos nossos).

Nas últimas três décadas, a área apresentou grande desenvolvimento de sua produçáo acadêmica, que além de contribuir com o desenvolvimento de novas e aprimoradas intervençóes profissionais nos mais variados campos das políticas sociais, objetivou-se em centenas de livros, artigos, resenhas [...] (Ciências Sociais, grifos nossos).

[...] a revista ___ foi, em sua gênese, contemporânea do importante movimento de renovaçáo do Serviço Social e continua contribuindo com o desenvolvimento acadêmico e profissional dessa área de conhecimento e intervençáo na realidade [...] (Ciências Sociais, grifos nossos).

Os periódicos analisados, assim como vários outros, estâo articulados à universidade, a algum programa de graduaçâo ou de pós-graduaçâo, conforme se apresenta no primeiro excerto "iniciativa do Departamento de Linguística". Sendo assim, há a noçâo de que a universidade é unidade que produz conhecimento, que se volta para a pesquisa, já que ela possibilita o "grande desenvolvimento de sua produçăo acadêmica". Ao se destinar à pesquisa, à extensâo e ao ensino, as universidades, junto com as revistas, contribuem realmente para o "desenvolvimento acadêmico e profissional", tendo em vista que propóe a liberdade para divulgar o saber, conforme os excertos seguintes:

Nas últimas três décadas, a área apresentou grande desenvolvimento de sua produçáo acadêmica, que além de contribuir com o desenvolvimento de novas e aprimoradas intervençôes profissionais [...] objetivou-se em centenas de livros, artigos, resenhas, e comunicaçóes de pesquisas (Ciências Sociais, grifos nossos).

[...] apresenta uma política editorial pautada pela diretriz de dar voz a essa valiosa produçáo acadêmica e profissional dos assistentes sociais (Ciências Sociais, grifos nossos).

Objetivos: Dar visibilidade à produçáo acadêmica e profissional de assistentes sociais e de pesquisadores [...] (Ciências Sociais, grifos nossos).

[...] a revista tem [apontado] para as diferentes tendências teórico-metodológicas da área, os artigos - em português, francês, espanhol ou inglês - permitem traçar um panorama histórico da Linguística Aplicada no Brasil, suas transformaçóes e sua consolidaçáo ao longo dos anos [...] (Linguística, Letras e Artes, grifos nossos).

De certa forma, a área de Ciências Sociais é bastante expressiva ao tratar do seu histórico, já que o apresenta detalhadamente, havendo, no sentido quantitativo, mais 
excertos do que se percebe em Linguística, Letras e Artes. Além de trazer em seu bojo a questăo da universidade, evidencia-se, em seu texto, a ideia de "liberdade de divulgaçâo do saber", estando bastante evidente quando se lê: "grande desenvolvimento de sua produçâo acadêmica [...] objetivou-se em centenas de livros, artigos, resenhas, e comunicaçóes de pesquisas". Há, assim, um discurso que perpassa os dizeres propostos pela revista de que há tal liberdade, principalmente no sentido de "dar visibilidade à produçăo". Outro momento em que se destaca tal discurso pode ser interpretado quando a revista apresenta o seu momento de nascimento:

O periódico nasceu na conjuntura do final do regime militar no Brasil, quando muitos movimentos sociais e populares questionavam o Estado autoritário e clamavam por liberdades democráticas. Momento também de fortes mobilizaçóes sindicais que levaram às grandes greves do $\mathrm{ABC}$ paulista e à fundaçăo do Partido dos Trabalhadores e da CUT (Ciências Sociais, grifos nossos).

A revista nasceu justamente em um momento em que se buscava a liberdade de divulgaçăo e se "clamava" pela liberdade do dizer, estabelecendo-se um diálogo intrínseco entre os discursos da CF (BRASIL, 1988). Há, assim, uma liberdade situada que năo prevê a repetiçăo de discursos, já que se opôe, por exemplo, ao período da ditadura. Busca-se a liberdade para publicaçấo, opondo-se ao caráter ditador do momento social em curso, caracterizando de que forma a revista concebe a vida em sociedade, devendo ser livre para que haja publicaçáo e circulaçáo do conhecimento.

Além disso, a área de Linguística, Letras e Artes ainda destaca que sua revista, durante anos, vem traçando um panorama histórico da Linguística Aplicada no país, o que remonta à ideia de divulgaçăo, de liberdade para se publicar, demarcando uma liberdade de expressáo dentro da área: "permitem traçar um panorama histórico da Linguística Aplicada no Brasil, suas transformaçóes e sua consolidaçăo ao longo dos anos $[\ldots]^{\prime \prime}$.

As Ciências Humanas também apresentam apontamentos quanto ao papel da universidade, respondendo aos pressupostos da CF (BRASIL, 1988): "Publicada pelo Departamento de História da Faculdade de Filosofia, Letras e Ciências Humanas da Universidade de Sáo Paulo (DH/FFLCH/USP)" (Ciências Humanas, grifos nossos).

Há, de certa forma, a noçấo de que as instituiçóes de ensino sâo unidades de conhecimento e pesquisa, fato que é reforçado dentro dos periódicos citados, principalmente ao mencionarem as faculdades, os departamentos e os cursos com os quais mantêm um vínculo, como se percebe nos excertos mencionados acima: "Departamento de História da Faculdade de Filosofia, Letras e Ciências Humanas da Universidade de Sáo Paulo". As áreas de Exatas, Saúde, Engenharias năo mencionam discurso quanto à universidade, tratando apenas da liberdade para a divulgaçăo trazida pela CF (BRASIL, 1988), conforme segue:

Com a intençăo de disseminar a produçáo científica em Educaçăo Matemática (Ciências Exatas, grifos nossos).

[...] publicar resultados de pesquisas de enfermagem e áreas afins que contribuam para o avanço do conhecimento científico [...] (Ciências da Saúde, grifos nossos).

Este periódico científico, de circulaçăo nacional e internacional, visa publicar avanços na pesquisa científica, tanto de pesquisadores atuantes no país como também de cientistas de outras nacionalidades (Engenharias, grifos nossos). 
Diante do exposto, o discurso que diz respeito à noçăo de liberdade para divulgar é bastante evidente no universo dos periódicos, principalmente no caso das Sociais e das Humanas. Talvez haja uma maior contextualizaçăo e relato do surgimento do periódico e de todo processo de sua constituiçăo por coerência aos seus próprios objetos de estudo que tratam, na maioria das vezes, da historicidade dos fatos, da vida em sociedade.

Logo, apesar de haver outros discursos na CF que discorrem sobre o ensino, como consta no Quadro 2, eles năo sâo fundamentais quando se pensa no papel da pesquisa, da produçấo e da divulgaçăo do conhecimento, já que tratam da obrigatoriedade do ensino fundamental e da educaçăo em âmbito geral. Como já foi evidenciado, o enfoque da CF năo é necessariamente a questăo da universidade e da produçăo científica, tendo seus preceitos ampliados dentro da LDB (BRASIL, 1996), conforme será abordado na sequência.

A LDB (BRASIL, 1996) traz, como primeiro discurso, a noçâo de educaçăo e a pesquisa no ensino superior, pensando justamente no aspecto social do trabalho e do uso social que o indivíduo faz dos conhecimentos. Contudo tal preceito é o único que năo é contemplado nos aspectos presentes nos periódicos, já que as revistas năo evidenciam preocupaçăo com uso dos conhecimentos por parte dos indivíduos, buscando, de certa forma, retratar o estímulo à produçáo, à circulaçăo, dentre outros fatores.

Nesse sentido, é que se trata do segundo ponto trazido pela LDB: o estímulo à criaçăo cultural, desenvolvendo nos sujeitos o espírito científico e, consequentemente, o pensamento reflexivo. A área que parece responder a esse discurso é de Ciências Sociais Aplicadas: "contribuir com o debate e o aprofundamento crítico e analítico da teoria social" (Ciências Sociais, grifos nossos). Ao fazer uso da expressáo "contribuir com o debate" talvez seja uma forma de mencionar o estímulo à criaçâo de ideias e ao desenvolvimento de um sujeito científico, perpassado por ideais, por temas e que auxilia no processo de debate por meio de sua produçấo publicada no periódico.

Outro aspecto apontado pela LDB se refere à possibilidade de desenvolver sujeitos aptos a serem inseridos nos mais diversos setores profissionais, levando ao desenvolvimento da sociedade brasileira. Das seis áreas analisadas, duas delas mencionam principalmente a questăo da sociedade, da realidade brasileira:

O periódico nasceu na conjuntura do final do regime militar no Brasil [...] (Ciências Sociais, grifos nossos).

[...] apresenta uma política editorial pautada pela diretriz de dar voz a essa valiosa produçáo acadêmica e profissional dos assistentes sociais [...] repercutindo também o desenvolvimento sociopolítico do Serviço Social (Ciências Sociais, grifos nossos).

[...] a revista __ foi, em sua gênese, contemporânea [...] e continua contribuindo com o desenvolvimento acadêmico e profissional dessa área de conhecimento e intervençáo na realidade (Ciências Sociais, grifos nossos).

[...] enfocando, preferencialmente, temas que dizem respeito à realidade brasileira e latino-americana (Ciências Sociais, grifos nossos).

[...] publica artigos, ensaios, resenhas [...] cujos focos relacionam-se ao ensino e à aprendizagem de Matemática e/ou ao papel da Matemática e da Educaçáo Matemática na sociedade (Ciências Exatas, grifos nossos). 
Mais uma vez, a área de Ciências Sociais Aplicadas se sobressai quanto ao aspecto da sociedade brasileira, ao abordar a questăo da necessidade de clamar por algo e dar voz à produçấo acadêmica e profissional, fazendo do sujeito alguém apto a auxiliar na melhoria da sociedade brasileira, o que remonta à noçăo de que as temáticas que săo abordadas sobre a vida social e enfocadas nos artigos, muitas vezes, sejam reflexo desse discurso maior que busca a historicidade e o aspecto social das coisas.

Quanto ao incentivo ao trabalho de pesquisa e de investigaçăo científica, destacamse as áreas que respondem ativamente aos documentos oficiais:

[...] sua missāo é divulgar artigos em português e espanhol [...] (Ciências Humanas, grifos nossos).

[...] grande desenvolvimento de sua produçáo acadêmica, que além de contribuir com o desenvolvimento [...] objetivou-se em centenas de livros, artigos, resenhas, e comunicaçóes de pesquisas (Ciências Sociais, grifos nossos).

Com a intençăo de disseminar a produçáo científica em Educaçăo Matemática [...] (Ciências Exatas, grifos nossos).

Este periódico científico, de circulaçăo nacional e internacional, visa publicar avanços na pesquisa científica [...] (Engenharias, grifos nossos).

Nos excertos apresentados, há uma evidência quanto ao incentivo ao trabalho de pesquisa e de investigaçăo, já que expōem a divulgaçăo de artigos, afirmam que contribuem para o estudo e o desenvolvimento da ciência, sendo apresentados os resultados em livros, artigos etc. Os periódicos buscam, entâo, disseminar a produçâo da ciência, publicando os avanços nas pesquisas e dialogando diretamente com os documentos. Duas revistas ainda afirmam o seguinte:

[...] apresenta uma política editorial pautada pela diretriz de dar voz a essa valiosa produçáo acadêmica e profissional dos assistentes sociais [...], repercutindo também o desenvolvimento sociopolítico do Serviço Social (Ciências Sociais, grifos nossos).

Apontando para as diferentes tendências teórico-metodológicas da área, os artigos [...] permitem traçar um panorama histórico da Linguística Aplicada no Brasil [...] (Linguística, Letras e Artes, grifos nossos).

O fato de "dar voz" e de realizar "um panorama histórico" sâo formas de demarcar o incentivo à produçăo acadêmica, ao mesmo tempo em que se fala da comunicaçăo dos saberes por meio da publicaçăo. Esse discurso está presente nos periódicos, năo sendo contemplado apenas pelas Ciências Exatas e Ciências da Saúde.

Outro discurso contemplado pela LDB é a "busca pela volta dos conhecimentos para a realidade da qual o sujeito faz parte", tornando-o insider (GEE, 1996), dentro de seu contexto social. As Ciências Sociais apresentam em seu objetivo o seguinte:

Dar visibilidade à produçáo acadêmica e profissional de assistentes sociais e de pesquisadores de áreas afins, bem como contribuir com o debate e o aprofundamento crítico e analítico da teoria social, enfocando, preferencialmente, temas que dizem respeito à realidade brasileira e latinoamericana (Ciências Sociais, grifos nossos).

Nâo há marcadamente algo que se refira à volta do pesquisador para sua realidade de origem, no entanto, fala-se dos assistentes sociais, fazendo-os aprofundar seus 
conhecimentos sobre teoria social, contemplando temas que se voltem à realidade brasileira. Logo, de forma geral, é possível inferir que os resultados das pesquisas voltaráo ou contribuirâo, de alguma forma, para a constituiçăo da realidade do país.

Esse discurso de os conhecimentos voltarem para a realidade também é contemplado na revista de Ciências da Saúde que traz, em seu bojo, ainda, o discurso de relacionar a formaçăo intelectual dos sujeitos e o mundo do trabalho: "A Revista [...] tem como missăo publicar resultados de pesquisas de enfermagem e áreas afins que contribuam para o avanço do conhecimento científico e para a prática profissional" (Ciências da Saúde, grifos nossos). Busca-se a relaçăo entre o intelecto e o mundo do trabalho, profissional. As outras áreas náo mencionam a questăo do profissional envolvido com a produção científica.

O PNE (BRASIL, 2014) também postula seus princípios, a saber: a universidade deve reunir a formaçâo intelectual e o trabalho; deve haver elevaçáo da qualidade da educaçấo superior e ampliar a proporçấo de mestres e doutores do corpo docente em efetivo exercício no ensino superior; institucionalizaçáo da pesquisa etc.

Na leitura dos periódicos científicos, constatou-se apenas a ideia de uniăo entre a formaçăo intelectual e o mundo do trabalho, que se fez presente nos periódicos das áreas de Ciências Sociais, Linguística, Letras e Artes e Ciências da Saúde:

[...] grande desenvolvimento de sua produçáo acadêmica, que além de contribuir com o desenvolvimento de novas e aprimoradas intervençóes profissionais nos mais variados campos das políticas sociais, objetivou-se em centenas de livros, artigos, resenhas, e comunicaçóes de pesquisas (Ciências Sociais, grifos nossos).

[...] dar voz a essa valiosa produçáo acadêmica e profissional dos assistentes sociais e de pesquisadores de áreas afins, repercutindo também o desenvolvimento sociopolítico do Serviço Social [...] (Ciências Sociais, grifos nossos).

[...] continua contribuindo com o desenvolvimento acadêmico e profissional dessa área de conhecimento e intervençăo na realidade (Ciências Sociais, grifos nossos).

[...] contribuam para o avanço do conhecimento científico e para a prática profissional (Ciências da Saúde, grifos nossos).

O discurso do PNE năo é tăo representativo dentro dos periódicos, assim como os da CF e da LDB. Há, na realidade, um foco bastante democrático no trato da ciência a partir de tais documentos, tendo em vista que o foco deles é necessariamente tratar de aspectos voltados à ciência, à sua publicaçăo e circulaçăo. Apesar de as revistas responderem, de alguma forma, ao discurso oficial desses documentos, será constatado que os elementos destacados pelo CNPq e Capes evidenciam-se fortemente nos periódicos, haja vista o caráter deliberativo que apresentam ao abordar as questóes de produçâo e de circulaçâo da ciência, havendo um enfoque bem delimitado para o assunto.

Para tratar dos discursos do CNPq e Capes, será seguida a própria sequência das revistas, que apresentam, em sua maioria, os seguintes elementos: histórico, comissâo editorial, conselho editorial, apoios/patrocinadores, indexadores.

O primeiro discurso trazido refere-se às condiçôes para que o $\mathrm{CNPq}$ e a Capes apoiem às revistas. Essas podem receber auxílio desde que sejam mantidas e editadas por instituiçâo ou sociedade científica brasileira, sem fins lucrativos, nacionais e que auxiliem para a elevaçâo do nível de qualidade das revistas voltadas à Ciência, Tecnologia e Inovaçấo, para divulgaçăo no Brasil e no exterior. 
Nas revistas das áreas, exceto na de Sociais, há o apoio dos órgăos de fomento, visto que sâo mantidas e editadas por "instituiçăo ou sociedade científica brasileira, sem fins lucrativos, nacionais". Tais informaçóes săo abordadas pela área de Ciências da Saúde tanto na parte introdutória da revista quanto na seçăo dos patrocinadores: "Fontes de financiamento: USP, CAPES, CNPq" (Patrocínio da revista - Ciências da Saúde); "A Revista é editada pela Escola de Enfermagem de Ribeiráo Preto da Universidade de Sáo Paulo, Centro Colaborador da OMS para o Desenvolvimento da Pesquisa em Enfermagem" (Parte introdutória - Ciências da Saúde, grifos nossos).

Quanto aos dados sobre "Apoios/Patrocínios da revista", caso a revista seja mantida e editada por instituiçâo ou sociedade brasileira, sem fins lucrativos, conforme já apontado, receberá auxílio do CNPq e da Capes: "Apoios: Universidade de Săo Paulo; Departamento de História da Faculdade de Filosofia; Capes [...]".(Ciências Humanas, grifos nossos); "A publicaçấo recebe financiamento de: Instituto de Estudos da Linguagem (www.iel.unicamp.br) e CNPq, CAPES, MEC" (Linguística, Letras e Artes); "Apoio financeiro do Programa Editorial do CNPq, CAPES e da Pró-reitoria de Pesquisa (PROPE) da UNESP" (Ciências Exatas, grifos nossos); "Fontes de financiamento: USP, CAPES, CNPq" (Patrocínio da revista - Ciências da Saúde); "A revista recebe apoio financeiro do: Programa de Apoio a Publicaçōes Científicas e CNPq, CAPES, MEC" (Engenharias).

A revista de Saúde responde ao esperado pelo CNPq e pela Capes, havendo o auxílio em sua confecçăo, conforme excertos extraídos da introduçăo e dos patrocinadores. As áreas de Linguística, Letras e Artes, Exatas e Engenharias tratam do fomento das agências apenas ao se referirem aos patrocinadores, conforme apresentado posteriormente.

Outro discurso marcado na parte introdutória dos periódicos é que as revistas que participam do Qualis săo constituídas por publicaçōes mencionadas anualmente pelos programas de pós-graduaçâo em virtude do Coleta de Dados da CAPES e que sâo classificadas de acordo com oito estratos, respectivamente: A1, A2, B1, B2, B3, B4, B5, C e com peso zero. Nos periódicos, essa informaçăo é recorrente: "A Revista __ está classificada na avaliaçấo Qualis 2013 no estrato A1 na área de História [...]" (Ciências Humanas, grifos do autor); "recente classificaçăo no Estrato A1 no Sistema Qualis Periódicos da CAPES/MEC" (Ciências Sociais Aplicadas, grifos nossos); "constar no Qualis (Qualis 1A)" (Linguística, Letras e Artes, grifos nossos); "[...] tendo sido avaliado como periódico QUALIS A1 na área de Ensino de Ciências e Matemática" (Ciências Exatas, grifos nossos); "Qualis na área de Enfermagem: A1" (Ciências da Saúde, grifos nossos).

Existem critérios para que os periódicos se originem e se mantenham no cenário acadêmico. Um deles, exigido pelo edital do CNPq/Capes, vem marcado logo na introduçâo de algumas revistas, referindo-se ao fato de elas terem $80 \%$ de artigos científicos originais. Apenas duas áreas tratam desse ineditismo: Ciências Humanas ("divulgar artigos originais inéditos") e Engenharias ("publicando resultados originais de pesquisas").

Outro critério apresentado surge nas seçôes de "Comissâo editorial" e "Conselho editorial", tratando da necessidade de as revistas perderem o caráter departamental, buscando colaboradores de outras instituiçôes nacionais e internacionais, por meio da revisăo por pares. Todas as revistas fazem referência a essa revisăo e à formaçâo dessas comissōes "mistas", integradas por sujeitos de outras instituiçôes nacionais 
e internacionais, possibilitando o diálogo com outras posturas e ideias. É uma forma de integrar ainda mais os membros que constituem a comunidade científica dentro das áreas de conhecimento. Para ilustrar, apresenta-se o exemplo da área de Ciências Humanas que é mantida pela Universidade de Săo Paulo (USP), tendo como membros da Comissāo atual professores da própria universidade, destacando como "Conselho editorial" professores de outras universidades, como "Universidade Federal Fluminense/ CPOC/Fundaçāo Getúlio Vargas; University of Maryland - EUA; Yale University - EUA; Universidade Federal do Pernambuco" etc.

O último elemento mencionado pelos periódicos, de forma geral, é o “Indexadores/ Fontes de indexaçăo", tratando da política de circulaçăo do conhecimento. Conforme discursos do CNPq e da Capes, ao indexar as revistas, os pesquisadores contam com a incorporaçăo de suas pesquisas nas bases de dados nacionais ou internacionais, havendo a estruturaçấo da informaçâo e do conhecimento que passa a se configurar como documentaçăo. O Brasil elaborou instrumentos para difusâo e circulaçăo do conhecimento: o SciELO, o Qualis e o Portal de Periódicos Capes que săo usados pelos periódicos das áreas de Ciências Humanas, Ciências Sociais, Ciências Exatas; os periódicos selecionados das áreas de Linguística, Saúde e Engenharias optam por indexadores internacionais.

Três discursos trazidos pelos documentos oficiais năo estăo marcados nos periódicos, a saber: (a) efeito de unidade da comunidade científica e da sociedade em relaçăo aos rumos dados à ciência e à tecnologia; (b) noçăo de ciência como tradicional, porque é imaginariamente tomada como una, homogênea, hierarquizada, apagando a diversidade teórica; (c) cada estado tem buscado desenvolver uma maneira de investir na pesquisa local, elaborando uma Fundaçăo de Amparo à Pesquisa (FAP), muitas das quais financiam publicaçōes científicas em periódicos.

Diante do número de ideias elencadas em relaçăo aos discursos do CNPq e da Capes, organiza-se o Quadro 3 que as retoma, identificando as áreas que respondem a cada uma delas, a partir da análise realizada nos periódicos.

\section{Quadro 3 - Discursos do CNPq e da Capes nos periódicos das diferentes áreas}

\begin{tabular}{c|c}
\hline $\begin{array}{c}\text { CNPq } \\
\text { Capes }\end{array}$ & PERIÓDICOS \\
\hline $\begin{array}{c}\text { Órgãos de fomento à pesquisa, criados em 1951 para estruturar uma política } \\
\text { científica no Brasil. }\end{array}$ & $\begin{array}{c}\text { Ciências Humanas. } \\
\text { Linguística, Letras e Artes. } \\
\text { Ciências Exatas. } \\
\text { Ciências da Saúde. } \\
\text { Engenharias. }\end{array}$ \\
\hline Política de Financiamento - CNPq/FAP. & $\begin{array}{c}\text { Linguística, Letras e Artes. } \\
\text { Ciências Exatas. } \\
\text { Ciências da Saúde. } \\
\text { Engenharias. }\end{array}$ \\
\hline Política de Avaliação - Capes. & $\begin{array}{c}\text { Ciências Humanas. } \\
\text { Linguística, Letras e Artes. } \\
\text { Ciências Exatas. } \\
\text { Ciências da Saúde. } \\
\text { Engenharias. }\end{array}$ \\
\hline Política de Circulação - SciELO/ISI. & Ciências Sociais Aplicadas. \\
Ciências Exatas.
\end{tabular}




\begin{tabular}{c|c}
\hline $\begin{array}{c}\text { CNPq } \\
\text { Capes }\end{array}$ & PERIÓDICOS \\
\hline $\begin{array}{c}\text { Efeito de unidade da comunidade científica e da sociedade em relação aos } \\
\text { rumos dados à ciência e à tecnologia. }\end{array}$ & Nenhum. \\
\hline $\begin{array}{c}\text { Noção de ciência como tradicional, porque é imaginariamente tomada como } \\
\text { una, homogênea, hierarquizada apagando a diversidade teórica. }\end{array}$ & Nenhum. \\
\hline $\begin{array}{c}\text { Cada estado tem buscado desenvolver uma maneira de investir na pesquisa } \\
\text { local, elaborando uma Fundação de Amparo à Pesquisa (FAP), sendo que } \\
\text { muitas delas financiam publicações científicas em periódicos. }\end{array}$ & Nenhum. \\
\hline $\begin{array}{c}\text { Priorizam-se as revistas eletrônicas, em todas as áreas do conhecimento. } \\
\text { Ciências Sociais Aplicadas. } \\
\text { Linguística, Letras e Artes. } \\
\text { Ciências Exatas. } \\
\text { Ciências da Saúde. } \\
\text { Engenharias. }\end{array}$ \\
\hline
\end{tabular}

Concede-se o apoio às revistas que são mantidas e editadas por instituição ou sociedade científica brasileira, sem fins lucrativos, nacionais e que auxiliem para a elevação do nível de qualidade das revistas voltadas à Ciência, Tecnologia e Inovação, para divulgação no Brasil e no exterior.

Ciências Humanas. Ciências Sociais Aplicadas. Linguística, Letras e Artes. Ciências Exatas.

Ciências da Saúde. Engenharias.

Os critérios para construção de revistas: devem apresentar 80\% de artigos científicos originais; devem perder o caráter departamental, buscando colaboradores de outras instituições nacionais e internacionais, havendo o estímulo para o intercâmbio entre as instituições e os grupos de pesquisa; a política editorial das revistas deve apresentar revisão por pares.

Ciências Humanas. Ciências Sociais Aplicadas. Linguística, Letras e Artes. Ciências Exatas.

Ciências da Saúde. Engenharias.

A Capes tem programas para acesso e divulgação da produção científica, como o Qualis.

Ciências Humanas.

Linguística, Letras e Artes. Ciências da Saúde.

Ciências Humanas.

Os periódicos que participam do Qualis são constituídos por publicações mencionadas anualmente pelos programas de pós-graduação em virtude do Coleta de Dados da Capes.

Ciências Sociais Aplicadas.

Linguística, Letras e Artes.

Ciências Exatas.

Ciências da Saúde. Engenharias.

Ciências Humanas.

O Conselho Técnico-Científico - CTC postulou que a classificação dos periódicos divulgados no Qualis das áreas fosse formada por oito estratos, respectivamente: $\mathrm{A} 1, \mathrm{~A} 2, \mathrm{~B} 1, \mathrm{~B} 2, \mathrm{~B} 3, \mathrm{~B} 4, \mathrm{~B} 5, \mathrm{C}$ e com peso zero.

Ciências Sociais Aplicadas.

Linguística, Letras e Artes.

Ciências Exatas.

Ciências da Saúde.

Ciências Humanas.

Ao indexar as revistas, os pesquisadores contam com a incorporação de suas pesquisas nas bases de dados nacionais ou internacionais, havendo a estruturação da informação e do conhecimento que passa a se configurar como documentação.

Ciências Sociais Aplicadas.

Linguística, Letras e Artes.

Ciências Exatas. Engenharias.

Ciências Humanas.

O Brasil criou instrumentos para difusão e circulação do conhecimento: SciELO e o Portal de Periódicos Capes.

Ciências Sociais Aplicadas.

Linguística, Letras e Artes.

Ciências Exatas. Engenharias.

Fonte: FUZA, 2015, p. 143.

Diante do exposto, os periódicos analisados dialogam e respondem aos discursos oficiais representados pela CF, LDB, PNE, Capes e CNPq em proporçōes variadas, sendo bastante evidente a resposta das revistas ao discurso dos dois últimos, em funçâo de seu caráter deliberativo e delimitado. De forma geral, CNPq e Capes, junto da comunidade 
acadêmica na qual se insere o periódico, constituem-se em interlocutor superior (o terceiro), cuja compreensáo responsiva o periódico pressupóe. O fato de haver esse diálogo evidencia as relaçôes de poder (JONES; TURNER; STREET, 1999) existentes nas práticas sociais de escrita, de produçăo e de circulaçăo do conhecimento, indicando que a utilizaçấo da linguagem envolve diferentes instâncias e se dá realmente em um elo discursivo contínuo.

\section{CONSIDERAÇÕES FINAIS}

Este artigo buscou sintetizar os resultados da pesquisa de Fuza (2015; 2016), realizando, especificamente, o recorte dos dados sobre os discursos dos documentos oficiais - Constituiçâo Federal do Brasil (CF, BRASIL, 1988); Lei de Diretrizes e Bases da Educaçăo Nacional (LDB, BRASIL, 1996); Plano Nacional da Educaçăo (PNE, BRASIL, 2014-2024), os discursos postulados pelas Agências de Fomento dos Estados, pela Capes e pelo CNPq - em diálogo com os dados coletados dos periódicos científicos, no que se refere a sua história, a sua comissâo, a seus indexadores etc.

O estudo de tais relaçôes de diálogo, de respostas das revistas aos documentos oficiais e às práticas de escrita, é uma forma de se verificar como os discursos ecoam ao serem concretizados, instituindo-se dentro das comunidades acadêmicas. Sendo assim, compreende-se o letramento acadêmico envolto por políticas científicas, pelas propostas dos discursos oficiais, pelos periódicos, pelos artigos etc., que se configuram como elos da cadeia dialógica da produçâo e da circulaçâo da ciência no país. 


\section{REFERÊNCIAS}

BAKHTIN, M. M. Os gêneros do discurso. In: Estética da criaçăo verbal. Traduçăo do russo por Paulo Bezerra. 4. ed. Sâo Paulo: Martins Fontes, 2003 [1979].

; VOLOCHINOV, V. N. Marxismo e filosofia da linguagem: problemas fundamentais do método sociológico na ciência da linguagem. Traduçâo do francês por Michel Lahud e Yara Frateschi Vieira. 9.ed. Săo Paulo: Hucitec, 1992 [1929].

BARATA, G. F. Nature e Sciencie: mudança na comunicaçăo da ciência e a contribuiçăo da ciência brasileira. Tese (Doutorado em História Social) - Universidade de Săo Paulo, Săo Paulo, 2010. Disponível em: < http://www.teses.usp.br/teses/disponiveis/8/8138/ tde-25112010-102319/pt-br.php>. Acesso em: 1 março 2016.

BRAIT, B. A natureza dialógica da linguagem: formas e graus de representaçâo dessa dimensâo cognitiva. In: Diálogos com Bakhtin. 3. ed. Curitiba: Editora da UFPR, 2001, pp. 69-92.

BRASIL, PNE. Plano Nacional de Educaçăo. Lei número 13005, de 25 de junho de 2014. Disponível em: 〈presrepublica.jusbrasil.com.br/legislaçâo125099097/lei-13005-14〉. Acesso em: 15 agost. 2014.

BRASIL, LDB. Lei de Diretrizes e Bases da Educaçâo Nacional. Lei número 9394, 20 de dezembro de 1996.

BRASIL. Constituiçăo (1988). Constituiçăo da República Federativa do Brasil. Brasília, DF: Senado Federal: Centro Gráfico, 1988.

CELLARD, A. A análise documental. In: POUPART, J.; DESLAURIERS, J. P; GROULX, L. H.; LAPERRIERE, A.; MAYER, R.; PIRES, A. P. A pesquisa qualitativa: enfoques epistemológicos e metodológicos. Petrópolis: Vozes, 2008.

COSTA, M. T. F. O uso de periódicos científicos electrónicos nas instituiçōes do Ensino Superior Público em Portugal. Dissertaçāo (Mestrado) - Departamento de Ciências Documentais, Universidade de Lisboa, Lisboa, 2008. Disponível em: <http://www.uc.pt/ sibuc/Pdfs/Tese_Teresa_Costa>. Acesso em: 10 maio 2016.

CRESPO, I. M.; CAREGNATO, S. E. Periódicos científicos eletrônicos: identificaçăo de características e estudo de três casos na área de Comunicaçăo. In: XVI Endocom - Encontro de Informaçăo em Ciências da Comunicaçăo, 2004. Anais eletrônicos... Disponível em: <http://www.portcom.intercom.org.br/institucional/a_rede/endocom/2004/Crespo. PDF>. Acesso em: 21 jan. 2013.

CURRY, M. J.; LILLIS, T. M. Strategies and tactics in academic knowledge production by multilingual scholars. Education Policy Analysis Archives, v. 22, n. 32, pp. 1-28, maio 2014. Disponível em: 〈http://dx.doi.org/10.14507/epaa.v22n32.2014〉. Acesso em: 15 set. 2014.

ENTENDACOMOFUNCIONAMASFUNDAÇŌESDEAMPAROÀPESQUISA. Disponívelem: $<$ http://noticias.universia.com.br/mobilidadeacademica/noticia/2003/12/18/526081/ entenda-como-funcionam-as-fundaes-amparo--pesquisa.html>.Acesso em: 20 agost. 2013. 
FAPESP. Código de Boas Práticas Científicas. 2012. Disponível em: <http:www.fapesp. br/6574>. Acesso em: 10 agost. 2013.

FIOCRUZ, Fundaçăo Oswaldo Cruz. A Internacionalizaçăo dos Periódicos Científicos Brasileiros. Disponível em: <http://periodicos.fiocruz.br/sites/default/files/anexos/ Carta\%20Forum\%20Editores\%20Fiocruz.pdf>. Acesso em: 01 março 2017.

FREITAS, M. H. A. Origens do Periodismo Científico no Brasil. Mestrado em História da Ciência - Pontifícia Universidade Católica de Sâo Paulo. 2005. 135f.

FUZA, A. F. A escrita acadêmico-científica como prática social: diálogos com os discursos oficiais. In: FIAD, R. Letramentos acadêmicos: contextos, práticas, percepçōes. Sâo Carlos: Pedro \& Joâo Editores, 2016, pp. 65-98.

A constituiçâo dos discursos escritos em práticas de letramento acadêmico-científicas. Tese (Doutorado em Linguística Aplicada) - Universidade Estadual de Campinas, Instituto de Estudos da Linguagem, Campinas, 2015.

GEE, J. P. Reading as situated language: a sociocognitive perspective. Journal of adolescent $\&$ adult literacy, Newark Delaware, v. 44, n. 8, pp. 714-725, 2001.

HAYASHIDA, S. R. A. C. Periódicos científicos: a produçăo e a circulaçăo da ciência da linguagem no Brasil. 2012. 245 f. Tese (Doutorado) - Instituto de Estudos da Linguagem, Universidade Estadual de Campinas, 2012.

JACOBINA, R. R. O paradigma da epistemologia histórica: a contribuiçăo de Thomas Kuhn. História, Ciências, Saúde-Manguinhos, Rio de Janeiro, ano VI, n. 3, p. 609-630, nov. 1999 - fev. 2000.

JONES, C.; TURNER, J.; STREET, B. (Orgs.). Students writing in the university: cultural and epistemological issues. Amsterdam: John Benjamins, 1999.

KRONICK, D. A. A History of Scientific and Technical Periodicals: the origines and development of scientific and techinical press. 2ed. Metuchen, NJ, Scarecrow, 1976.

KUHN, T. S. A estrutura das Revoluçōes Científicas. Săo Paulo: Perspectiva, 1990.

MEADOWS, A. J. A comunicaçăo científica. Traduçăo de Antonio Agenor Briquet de Lemos. Brasília, DF: Briquet de Lemos, 1999.

OLIVEIRA, E. F. Letramento acadêmico: concepçôes divergentes sobre o gênero resenha crítica. Dissertaçăo (Mestrado) - Universidade Estadual de Campinas, Instituto de Estudos da Linguagem, Campinas-SP, 2010.

OLIVEIRA, E. B. P. M. Uso de periódicos científicos eletrônicos por docentes e pós-graduandos do Instituto de Geociências da USP. (Dissertaçăo de Mestrado em Ciência da Informaçāo) - Universidade de Sáo Paulo, São Paulo, 2006. Disponível em <http://www. teses.usp.br/teses/disponiveis/27/27151/tde-18122006-02446/publico/Erica.pdf.>. Aceso em: 20 fev. 2013.

PASQUOTTE-VIEIRA, E. A. Letramentos Acadêmicos: (re)significaçóes e (re)posicionamentos de sujeitos discursivos. (Tese de doutorado em Linguística Aplicada) Universidade Estadual de Campinas, Instituto de Estudos da Linguagem. Campinas, SP: [s.n.], 2014. 
RODRIGUES, J. G.; MARINHO, S. M. O. X. A trajetória do periódico científico na Fundaçăo Oswaldo Cruz: perspectivas da Biblioteca de Ciências Biomédicas. História, Ciências, Saúde - Manguinhos, Rio de Janeiro, v.16, n.2, abr.-jun. 2009, pp. 523-532.

SILVA, J. R. S.; ALMEIDA, C. D.; GUINDANI, J. F. Pesquisa documental: pistas teóricas e metodológicas. Revista Brasileira de História \& Ciências Sociais, ano I, n. 1, pp. 1-15, julho, 2009.

SCHWARTZMAN, S. Um espaço para a ciência: a formaçăo da comunidade científica no Brasil. Traduçâo de: The development of the scientific community in Brazil. Tradutores: Sérgio Bath e Oswaldo Biato. Brasília: Ministério da Ciência e Tecnologia, Centro de Estudos Estratégicos, 2001.

STREET, B. Literacy in theory and practice. Cambridge: Cambridge University Press, 1984.

STUMPF, I. R. C. Passado e futuro das revistas científicas. Ciência da Informaçăo. v. 25, n. 3, pp. 1 - 6, 1996.

Disponível em: <http://revista.ibict.br/ciinf/index.php/ciinf/article/viewFile/463/422〉. Acesso em: 20 fev. 2013. 